„TURYZM" 1996, t. 6, z. 1

Dorian Grzelka

\title{
LOKALIZACJA BIUR PODRÓŻY NA TERENIE ŁODZI
}

\section{LA LOCALISATION DES AGENCES DE VOYAGES SUR LE TERRAIN DE ŁÓDŹ}

LOCALISATION OF TRAVEL AGENCIES IN LÓDŹ

Opracowanie zawiera rezultaty badania, którego celem było poznanie lokalizacji biur turystycznych na terenie Łodzi oraz określenie $\mathrm{i}$ analiza czynników o niej decydujących.

\section{WSTĘP}

„Lokalizacja” oznacza położenie obiektu w przestrzeni względem innych jej elementów. Pojęcie to obejmuje cztery składowe: obiekt zlokalizowany (w tym przypadku biuro turystyczne), miejsce lokalizacji (lokację), cel oraz motywy (czynniki) lokalizacji (Slownik..., 1982). W artykule tym zostaną omówione wszystkie te elementy.

Biura podróży odgrywają obecnie znaczną rolę w dystrybucji produktu turystycznego, który stanowi ofertę ich sprzedaży. Są one głównym pośrednikiem między klientem-turystą a dobrami, towarami i usługami stanowiącymi produkt turystyczny. Jednocześnie biura podróży w większości są ściśle związane z obszarami generującymi ruch turystyczny. Dlatego też ważnym problemem jest zbadanie i analiza cech warunkujących ich lokalizację na terenie dużego miasta, jakim jest Łódź. Jest to zadanie ważkie, zwłaszcza że zagadnienie to nie zaznacza się w wyraźny sposób w literaturze dotyczącej zarówno lokalizacji usług, jak i geografii turyzmu. Można postawić też tezę, iż biura turystyczne skupiają się w dzielnicy centralnej (CBD - Central Business District), będąc jednocześnie same jej wyznacznikiem. 


\section{BIURO TURYSTYCZNE}

Wzrost aktywności turystycznej w XIX w. wywołał pojawienie się biur podróży. Przełomowy był rok 1841, kiedy to Thomas Cook zorganizował wycieczkę kolejową na trasie Leicester-Lughborough. Fakt ten w literaturze przedmiotu uważa się za narodziny pierwszego biura turystycznego, choć już w starożytnym Rzymie kancelaria cesarska dysponowała osobliwym dzialem - Państwowym Biurem Podróży (Officium de Facere Evectionem). Z uslug Towarzystwa Cooka poza Brytyjczykami korzystali również mieszkańcy wielu innych państw, nie tylko europejskich. W roku 1876 powstala w Anglii firma Wagons Lits, która połączyła się w 1929 r. z Towarzystwem Cooka. W innych krajach biura podróży tworzyły się $w$ różnych okresach. W Niemczech pierwsze pojawiły się w latach 1842 i 1863 w Berlinie, we Włoszech w 1897 r. w Rzymie. W Stanach Zjednoczonych American Express zorganizowano dopiero w 1918 r. na bazie drobnych przedsiębiorstw, powstałych w latach osiemdziesiątych i dziewięćdziesiątych XIX stulecia (W a r s z y ń s k a, J a c k o w s k i 1979).

Biura turystyczne w Polsce zaczęły powstawać na przełomie XIX i XX w. Były to $w$ większości przedstawicielstwa linii żeglugowych zajmujących się przewozem emigrantów (np. Cunart \& White Star Line, Hapag, Nord Deutscher Loyd). Głównym terenem ich działalności była Galicja. Niektórzy agenci usamodzielniali się tworząc własne, ,polskie”, biura podróży.

Pierwszym biurem turystycznym w nowoczesnym tego słowa znaczeniu był w Polsce „Orbis”, prywatna spółka założona w 1923 r. we Lwowie. Po przeniesieniu do Warszawy w 1929 r. i wykupieniu w 1933 r. przez państwo większości akcji stała się ona wielkim przedsiębiorstwem funkcjonującym do dziś. Oprócz tego w okresie międzywojennym powstały: delegatura na Polskę Wagons Lits/Cook, Poltur - biuro podróży PTTK, Icar, Frankpol, Spółdzielnia Turystyczno-Wypoczynkowa Gromada.

Po II wojnie światowej do 1956 r. działało tylko BP Orbis. Następnie powstały: BTM Juventour, BPiT Almatur, SBT Turysta, PPISiT Sports-Tourist, biura podróży PTTK i PZMot, OST Gromada (reaktywowana w 1957 r.), BTC Camptur, BUT Harctur, BPiT Logostur i inne. W latach osiemdziesiątych rozpoczął się proces tworzenia prywatnych biur turystycznych.

W 1938 r. na terenie Łodzi istniało pięć biur podróży. Były to: Wagons Lits/Cook, Orbis, Argos, Frankpol, Poltur. Po II wojnie światowej tak jak na terenie kraju, tak i na obszarze Łodzi liczba biur podróży zwiększała się wraz ze wzrostem ruchu turystycznego i zmianami w sytuacji polityczno-ekonomicznej Polski prowadzącymi w kierunku gospodarki rynkowej. Zmieniało się również w czasie ich rozmieszczenie na terenie miasta. Do jego analizy wybrano trzy lata: 1981, 1991, 1994.

Do roku 1981 działało w Łodzi 10 biur turystycznych. Dalszych 5 powstało w latach 1981-1988. W 1991 r. zarejestrowanych było ponad 60 biur podróży. 
W wyniku kwerendy przeprowadzonej w 1994 r. stwierdzono, że istniało wtedy już 198 biur. Kwerenda objęła ich stan prawno-organizacyjny, rok założenia, charakter i wyposażenie zajmowanego lokalu, wielkość zatrudnienia oraz zakres świadczonych usług turystycznych.

Z powyższych danych wynika, iż w latach 1981-1991 nastapił ponad sześciokrotny wzrost liczby biur podróży, a 1991-1994 trzykrotny. Gdy w latach 1989-1991 tworzyło się średnio w ciągu roku 16 nowych biur, to 1992-1994 po 45 (jednak w 1994 r. tylko 6). Najwięcej biur turystycznych powstało więc w 1992 i 1993 r.

Wśród liczby 198 biur duża ich część jest słaba ekonomicznie i będzie musiała zniknąc z rynku. Niektóre z nich ratując się przed upadłością prowadzą działalność turystyczną razem z handlową (staje się ona czasem wiodąca), bądź pracują sezonowo - w okresie letnim. Jednocześnie należy wspomnieć, że określenie liczby biur podróży działających $\mathrm{w}$ danych latach jest trudne, co wynika $\mathrm{z}$ dużej płynności $\mathrm{w}$ ich powstawaniu, działalności i likwidacji, zakładania biur, lecz nie podejmowania przez nie działalności usługowej, prowadzenia dodatkowo obsługi turystycznej przez niektóre inne firmy.

W biurach podróży w 1994 r. pracowało na stałe 675 osób (średnie zatrudnienie wynosiło na jedno biuro ok. 3 osoby), gdy w 1991 r. ok. 500 osób (średnie zatrudnienie na jedno biuro przekraczało 15 osób). Taka sytuacja spowodowana została powstaniem wielu jedno- $\mathrm{i}$ dwuosobowych przedsiębiorstw oraz redukcją zatrudnienia w dużych firmach. Angażuje się też wielu pracowników sezonowo i na pół etatu.

W 1990 r. łódzkie biura podróży obsłużyły 307,7 tys. osób (M a t c z a k 1994), gdy w 1993 r. 221,1 tys. osób, nastapił więc spadek o $28,1 \%$. Jest to zjawisko bardzo niekorzystne, wpływające na rentowność tych jednostek (średnio na jedno biuro w 1990 r. przypadało 4884 klientów, gdy w 1993 r. 1116). W 1990 i 1993 r. większość osób obsłużonych stanowili turyści korzystający z oferty zagranicznych wyjazdów (głównie tanich o niskim standardzie), bo odpowiednio 160,3 tys. $(52,1 \%)$ i 119,8 tys. osób $(54,0 \%)$.

\section{LOKALIZACJA BIUR TURYSTYCZNYCH}

W celu analizy zmian w lokalizacji biur turystycznych na terenie Łodzi w wyżej wymienionych latach ( $w$ badaniach brano pod uwagę fakt istnienia biura) posłużono się następującymi metodami. Wyliczono i zaznaczono na mapie takie miary centrograficzne, jak: średnie arytmetyczne przestrzenne - Sc (centroidy) i mediany przestrzenne - MEp. Jako miarę rozrzutu przestrzennego zastosowano odległość standardową- $S D$. Obliczono ją wg wzoru:

$$
S D=\sqrt{s_{x}^{2}+s_{y}^{2}}
$$


gdzie: $s_{x}^{2}$ i $s_{y}^{2}$ są wariancjami współrzędnych południkowych i równoleżnikowych układu punktów. Biura zlokalizowano na planie Łodzi, na który nałożona została siatka $\mathrm{z}$ układem współrzędnych. Na podstawie wyznaczonych wartości rzędnych i odciętych wyliczono wyżej wymienione współczynniki. Zastosowano też metodę koncentracji. Wyraża się ona $\mathrm{m}$. in. stosunkiem koncentracji $K$ wyliczonym wg wzoru:

$$
K=1-\frac{1}{5000} \sum \frac{s_{i}\left(M_{i-1}+M_{i}\right)}{2}
$$

gdzie: $s_{i}$ - powierzchnia urbanistycznej jednostki osiedlowej wyrażona w procentach, $M_{i}$ - kumulowany odsetek liczby biur podróży w jednostce $i, M_{i-1}$ kumulowany odsetek liczby biur podróży w jednostce poprzedzającej $i$. Dla roku 1994 sporządzono mapę koncentracji, za podstawę której przyjęto podział Łodzi na urbanistyczne jednostki bilansowe. Dla wszystkich lat zestawiono mapy wykonane metodą punktową przedstawiające rozmieszczenie biur.

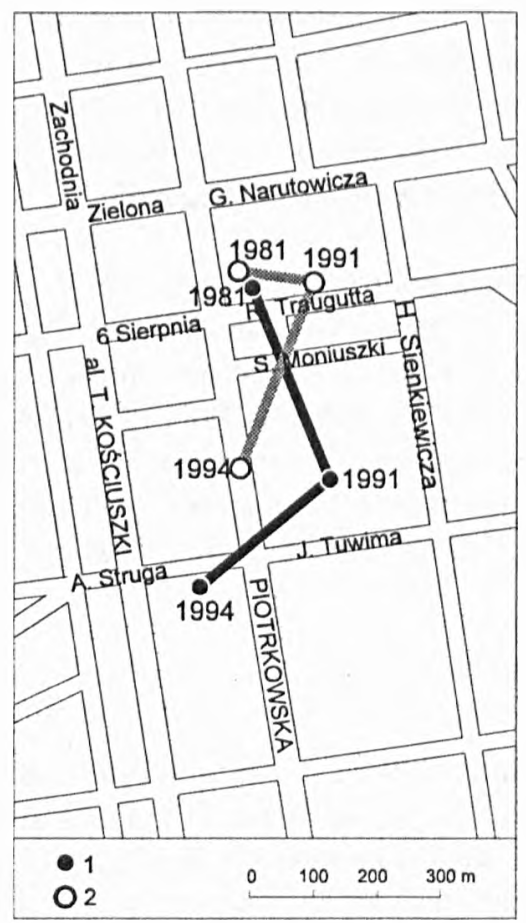

Rys. 1. Ruch centroidu i mediany przestrzennej biur podróży na terenie Łodzi w latach 1981-1994: 1 - centroid, 2 -mediana przestrzenna

Dessin 1. Le mouvement du centroïde et de la médiane spatiale des agences de voyages sur le terrain de Łódź dans les années 1981-1994: 1 - centroïde, 2-médiane spatiale 
Z przeprowadzonej analizy wynika, iż wraz ze wzrostem liczby biur podróży w latach 1981-1994 zmieniała się lokalizacja ich mediany przestrzennej i centroidu w przestrzeni miejskiej Łodzi (rys. 1). W 1981 r. mediana przestrzenna i centroid znajdowały się bardzo blisko siebie na działce budowlanej u zbiegu ulic Piotrkowskiej i R. Traugutta, w pobliżu BP Orbis i PTTK. W 1991 r. mediana przestrzenna przesunęła się o $100 \mathrm{~m}$ na wschód wzdłuż ul. R. Traugutta, a środek ciężkości o $300 \mathrm{~m}$ na południowy wschód w kierunku ul. J. Tuwima. W 1994 r. centroid znajdował się $250 \mathrm{~m}$ na południowy zachód przy ul. A. Struga, w połowie drogi między Piotrkowską a al. T. Kościuszki, natomiast mediana przestrzenna $300 \mathrm{~m}$ na południowy zachód, na ul. Piotrkowskiej między pasażem Rubinsteina a ul. A. Struga.

Generalną tendencja jaką można zauważyć jest wędrówka centroidu i mediany przestrzennej w kierunku południowym miasta, w pierwszym przypadku o $450 \mathrm{~m}$, a w drugim o $300 \mathrm{~m}$. Tak więc większość nowych biur turystycznych lokowana jest cały czas w znaczniejszej części w poludniowych dzielnicach miasta, z tym że w $1991 \mathrm{r}$. bardziej w południowo-wschodnich, a w $1994 \mathrm{r}$. bardziej w południowo-zachodnich. Większa rozpiętość w przesunięciach centroidu spowodowana jest tym, że jest on bardziej wrażliwy na wartości skrajne od mediany przestrzennej.

Odległość standardowa $D S$ mierzy dyspersję odległości wszystkich biur na terenie Lodzi od ich centroidu. Dyspersja ta rośnie wraz z rozprzestrzenianiem się biur turystycznych na obszarze miasta. W 1981 r. wartość $D S$ wynosiła $0,73 \mathrm{~km}$, a w 1991 i $1994 \mathrm{r}$. odpowiednio $1,35 \mathrm{~km}$ oraz $1,87 \mathrm{~km}$. Tak więc średnia odległość statystycznego biura od średniej arytmetycznej przestrzennej wzrosła między rokiem 1981 a 1994 o 1,14 km.

Zmianom w badanym okresie ulegała też koncentracja biur podróży, która zmniejszała się. Gdy w $1981 \mathrm{r}$. współczynnik koncentracji K wynosił 0,991 , to w roku $1991-0,980$, a $1994-0,939$. Jednak we wszystkich tych trzech przypadkach koncentracja jest bardzo wysoka.

W 1981 r. 100\% (10) biur podróży znajdowało się na obszarze trzech śródmiejskich jednostek urbanistycznych położonych wzdłuż ul. Piotrkowskiej 401, 406, 407, których obszar stanowi 1,3\% powierzchni Łodzi. W 1991 r. na terenie tych jednostek mieściło się 74,54\% (47) biur turystycznych, a w 1994 już tylko $55,63 \%$ (110). W $1991 \mathrm{r}$. biura podróży rozprzestrzeniły się na obszarze miasta na najbliższe osiem nadal położonych centralnie jednostek urbanistycznych, jednocześnie nie występowały one na 95,7\% powierzchni Lodzi (rys. 2). W 1994 r. nastapił dalszy proces dekoncentracji położenia biur turystycznych. Nie występowały one już tylko na 76,8\% powierzchni Łodzi (rys. 2, 3). Rozprzestrzeniły się one w niewielkim stopniu na obszary nowych osiedli mieszkaniowych (Retkinia, Radogoszcz, Dąbrowa, Widzew Wschód). Jednocześnie jednak na terenie tych samych jednostek co w 1991 r. znajdowało się $72,46 \%$ (143) biur. 

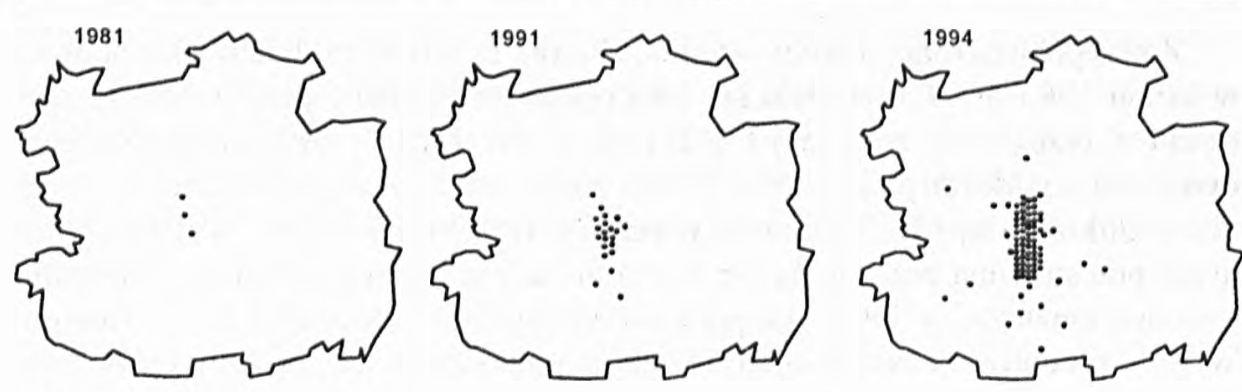

$\cdot 3$ biura

Rys. 2. Rozmieszczenie biur podróży na terenie Lodzi w latach 1981-1994

Dessin 2. La localisation des agences de voyages sur le terrain de Łódź dans les années 1981-1994

Na podstawie wyżej przedstawionych danych można stwierdzić, że biura turystyczne są ściśle związane z centrum miasta. Większość zlokalizowana była w 1994 r. w obrębie dzielnicy Śródmieście - 57,6\% to jest 114 (w 1990 r. aż $90 \%$ ). Potwierdzeniem tych spostrzeżeń jest fakt, iż centroid biur podróży
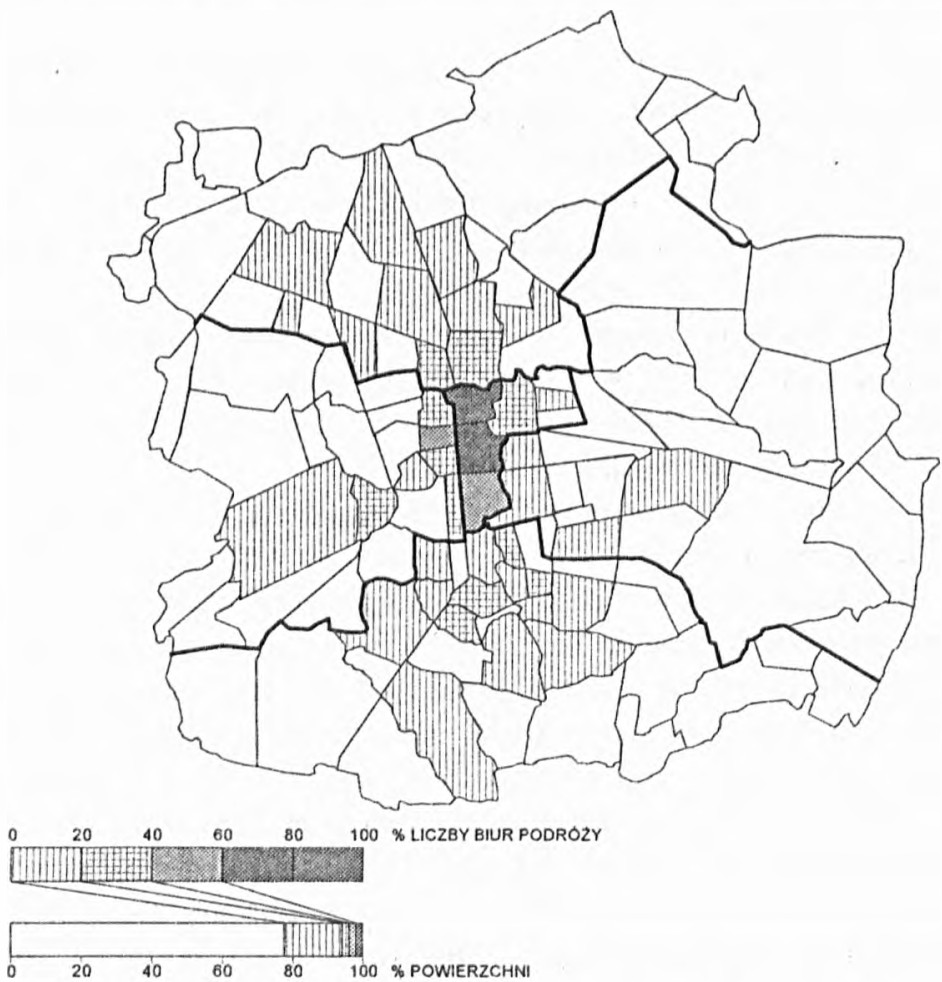

Rys. 3. Stopień koncentracji biur turystycznych na terenie Łodzi w 1994 r.

Dessin 3. Le degré de la concentration des agences de voyages sur le terrain de Lódź en 1994 
w 1994 r. położony jest bardzo blisko - 75 m na zachód - od centroidu wyznaczającego centrum Łodzi (znajduje się on na skrzyżowaniu ul. Piotrkowskiej $\mathrm{z}$ ul. A. Struga i J. Tuwima) i tak jak on przemieszcza się w kierunku południowym.

Środek grawitacji oznaczający centrum Łodzi wyznaczono biorąc pod uwagę instytucje świadczące usługi wyższego rzędu, tj. banki i ubezpieczenia, instytucje naukowe, kliniki i wyspecjalizowane szpitale, wymiar sprawiedliwości, środki masowego przekazu, centrale wielkich biur, komunikację i łączność, kulturę, administrację sensu largo i inne instytucje o charakterze wielkomiejskim (W o l a n i u k 1994). W dzielnicy centralnej koncentrują się też najbardziej reprezentacyjne domy towarowe i specyficzne sklepy.

W 1993 r. przeprowadzono inwentaryzację placówek handlowych, usługowych i pozostałych instytucji. Wyznaczone w ten sposób centrum handlowo-usługowo-instytucjonalne obejmowało obszar zamknięty ulicami: OgrodowąPółnocną-Kilińskiego-Żwirki i Wigury-Kościuszki-Mickiewicza-ŻeromskiegoLegionów-Gdańska. Na tym terenie znajdowało się w 1994 r. 100 (51\%) biur turystycznych.

T a bela I

Rozmieszczenie biur podróży wg kryterium bezpośredniości stosunku do klienta na terenie Lodzi w $1994 \mathrm{r}$.

La localisation des agences de voyages sur le terrain de Łódź selon le critère du contact direct avec le client en 1994

\begin{tabular}{|c|c|c|c|c|c|c|c|c|}
\hline \multirow{3}{*}{$\begin{array}{c}\text { Biura wg bezpośredniości } \\
\text { stosunku do klienta }\end{array}$} & \multicolumn{8}{|c|}{ Biura w poszczególnych strefach } \\
\hline & \multicolumn{2}{|c|}{$\begin{array}{c}\mathrm{I} \\
0,0-1,5 \mathrm{~km}\end{array}$} & \multicolumn{2}{|c|}{$\begin{array}{c}\text { II } \\
1,5-3,0 \mathrm{~km}\end{array}$} & \multicolumn{2}{|c|}{$\begin{array}{c}\text { III } \\
3,0-6,0 \mathrm{~km}\end{array}$} & \multicolumn{2}{|c|}{ razem } \\
\hline & liczba & $\%$ & liczba & $\%$ & liczba & $\%$ & liczba & $\%$ \\
\hline 1. Detaliści & 32 & 26,0 & 27 & 79,4 & 32 & 78,0 & 91 & 46,0 \\
\hline 2. O profilu mieszany'm & 91 & 74,0 & 7 & 20,6 & 9 & 22,0 & 107 & 54,0 \\
\hline a) producent-hurtownik- & & & & & & & & \\
\hline -detalista & 11 & 8,9 & - & - & - & - & 11 & 5,6 \\
\hline b) hurtownik-detalista & 6 & 4,9 & - & - & - & - & 6 & 3,0 \\
\hline c) producent-detalista & 74 & 60,2 & 7 & 20,6 & 9 & 22,0 & 90 & 45,4 \\
\hline Ogółem & 123 & 100,0 & 34 & 100,0 & 41 & 100,0 & 198 & 100,0 \\
\hline
\end{tabular}

Centrum miastá wyróżnia się spośród innych terenów miejskich koncentracją unikalnych instytucji usługowych, obejmujących sferę życia politycznego i administracyjnego, gospodarczego, społecznego, kulturalnego, rozrywkowego, dobrą dostępnością komunikacyjną. Jest miejscem spotkań zarówno świata biznesu, jak $\mathrm{i}$ całego społeczeństwa przybywającego tu w określonym celu. Jest 
tym osobliwym „forum” życia miejskiego, w którym dochodzi do wymiany dóbr, myśli, zaspokajania potrzeb podstawowych jak i wyższego rzędu. Tutaj także tworzy się specyficzny klimat miasta (W o l a n i u k 1994).

Choć w dzielnicy śródmiejskiej typu „city” mieszka na stałe mała liczba ludności, to dużo osób pracuje tu i dojeżdża codziennie, by załatwić swoje sprawy. Na ul. Piotrkowskiej, która jest osią „łódzkiego CBD”, koncentruje się największy w tym mieście ruch pieszy $\mathrm{z}$ uwagi na nagromadzenie instytucji typu wielkomiejskiego. W 1992 r. mieściło się tu: 12 placówek prowadzących działalność finansowo-ubezpieczeniową, 19 w zakresie ochrony zdrowia, 14 oświaty i wychowania, 2 kultury i sztuki, 3 łączności oraz 8 naukowych. Ponadto ulokowały się tu 33 restauracje, 365 sklepów różnej branży i innych obiektów prowadzących działalność handlową (P a c h o l c z y k 1993). Znajduje się tam również znaczna liczba biur podróży, bo $44(22,2 \%)$. Szczególna koncentracja widoczna jest na odcinku od pl. Wolności po al. J. Piłsudskiego.

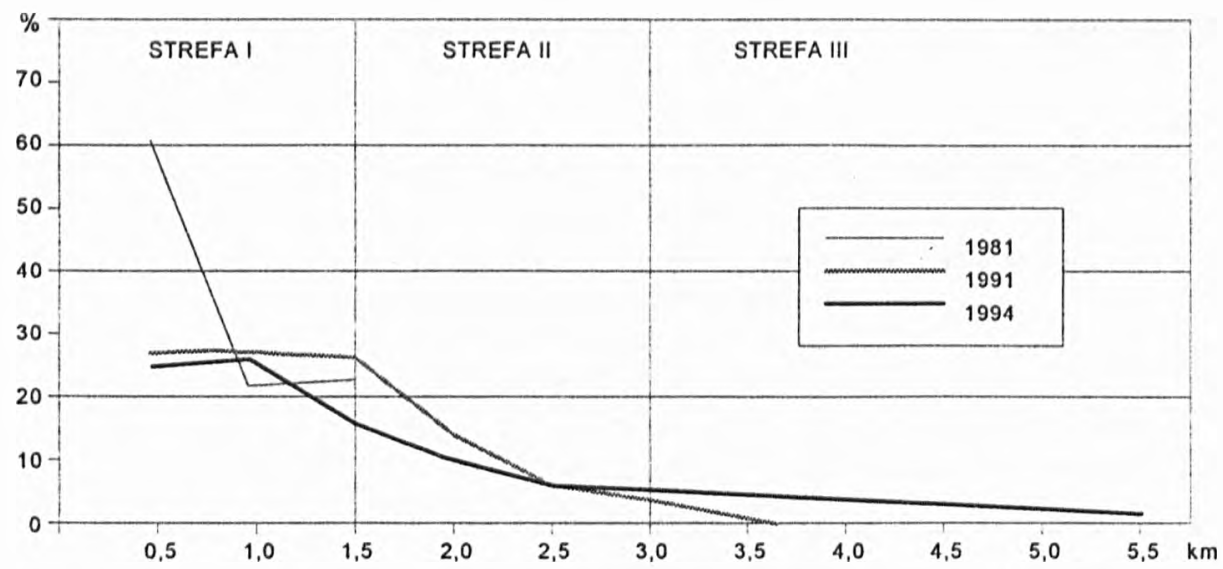

Rys. 4. Liczba biur podróży w zależności od odległości od wyznaczonego środka ciężkości

Dessin 4. Le nombre des agences de voyages selon l'éloignement du centre de gravité fixé

Reasumując można stwierdzić, że większość biur podróży pełni funkcje centralne, wielkomiejskie i skupiając się w dzielnicy typu „city” może stać się jednym z jej wyznaczników. Spowodowane jest to tym, iż centrum miasta $z$ uwagi na duży ruch i pełnione funkcje jest teoretycznie najlepszym miejscem do lokalizacji tego typu instytucji usługowych jak biura podróży.

Rozmieszczenie biur turystycznych na terenie Łodzi zanalizowano też w zależności od odległości od wyznaczonego środka ciężkości dla trzech badanych lat: 1981, 1991, 1994 (rys. 4, tab. II ). W tym celu wyznaczono trzy strefy, które w formie coraz większych pierścieni okalają dzielnicę śródmiejską. Za strefę I 
Liczba biur podróży w poszczególnych strefach odległości w zależności od daty powstania

Le nombre des agences de voyage dans les zones particulières de distance selon la date de fondation

\begin{tabular}{|c|c|c|c|c|c|c|c|c|c|c|c|c|c|c|c|c|}
\hline \multirow{4}{*}{$\begin{array}{c}\text { Data } \\
\text { powstania }\end{array}$} & \multicolumn{16}{|c|}{ Biura w poszczególnych strefach } \\
\hline & \multicolumn{4}{|c|}{$\begin{array}{c}\mathrm{I} \\
0,0-1,5 \mathrm{~km}\end{array}$} & \multicolumn{4}{|c|}{$\begin{array}{c}\text { II } \\
1,5-3,0 \mathrm{~km}\end{array}$} & \multicolumn{4}{|c|}{$\begin{array}{c}\text { III } \\
3,0-6,0 \mathrm{~km}\end{array}$} & \multicolumn{4}{|c|}{ razem } \\
\hline & \multirow{2}{*}{ liczba } & \multirow{2}{*}{$\%$} & \multicolumn{2}{|c|}{ kumulowane } & \multirow{2}{*}{ liczba } & \multirow{2}{*}{$\%$} & \multicolumn{2}{|c|}{ kumulowane } & \multirow{2}{*}{ liczba } & \multirow{2}{*}{$\%$} & \multicolumn{2}{|c|}{ kumulowane } & \multirow{2}{*}{ liczba } & \multirow{2}{*}{$\%$} & \multicolumn{2}{|c|}{ kumulowane } \\
\hline & & & liczba & $\%$ & & & liczba & $\%$ & & & liczba & $\%$ & & & liczba & $\%$ \\
\hline do 1981 & 10 & 8,1 & 10 & 8,1 & - & - & - & - & - & - & - & - & 10 & 8,1 & 10 & 8,1 \\
\hline $1982-1988$ & 5 & 4,1 & 15 & 12,2 & - & - & - & - & - & - & - & - & 5 & 4,1 & 15 & 12,2 \\
\hline $1989-1991$ & 32 & 26,0 & 47 & 38,2 & 13 & 38,3 & 13 & 38,2 & 3 & 7,3 & 3 & 7,3 & 48 & 24,2 & 63 & 36,4 \\
\hline $1992-1994$ & 76 & 61,8 & 123 & 100,0 & 21 & 61,8 & 34 & 100,0 & 38 & 92,7 & 41 & 100,3 & 136 & 68,1 & 198 & 100,0 \\
\hline Ogólem & 123 & 100,0 & - & - & 34 & 100,0 & - & - & 41 & 100,0 & - & - & 198 & 100,0 & - & - \\
\hline
\end{tabular}


przyjęto okrag o promieniu $1,5 \mathrm{~km}$ od centroidu, druga (II) - przejściowa - zawiera się między okręgami o promieniach 1,5-3 km, trzecia (III) - dużych osiedli mieszkaniowych - znajduje się w odległości 3-6 km w linii prostej od centroidu. Powyżej $6 \mathrm{~km}$ od niego biura podróży nie wystepują. Analizując rys. 4 i tabelę I można stwierdzić, że podczas rozwoju przestrzennego i ilościowego biur turystycznych na terenie miasta, w okręgach położonych centralnie spada ich procentowy udział, a liczba bezwzględna rośnie.

$\mathrm{Na}$ tej podstawie można wysnuć wniosek, że zjawisko rozprzestrzeniania się biur turystycznych na obszarze miasta jest procesem dyfuzji innowacji. Wymaga to jednak przyjęcia założenia, iż elementem podlegającym dyfuzji jest atrakcyjność różnych jego obszarów jako miejsca lokalizacji biur podróży. Jest to jednocześnie proces ekspansji, tzn., że zjawisko podlegające dyfuzji nie zanika na obszarze początkowym, lecz zwykle nasila się oraz rozprzestrzenia na inne tereny. Modele dyfuzji były z pozytywnymi rezultatami wykorzystane $\mathrm{m}$. in. przez T. Hägerstranda do badań rozchodzenia się innowacji z dziedziny rolnictwa, przez J. Colemana, który zajął się szybkością rozprowadzania nowych lekarstw, J. Łobodę do badań procesu upowszechniania się telewizji w Polsce w latach 1961-1968.

Proces dyfuzji informacji wykazuje charakterystyczne prawidłowości czasowe i przestrzenne. Jego ogólny schemat logiczny w odniesieniu do biur turystycznych można przedstawić w poniższy sposób. Początkowo liczby osób, które odebrały informację, wzrastają powoli - powoli rośnie liczba biur podróży, np. z 10 w 1981 r. do 15 w 1988 r. Z upływem czasu, w miarę jak wzrasta liczba źródeł, zwiększanie się liczby odbiorców ulega przyspieszeniu - liczba biur turystycznych wzrasta z 63 w 1991 r. do 192 w 1993 r. W końcowym okresie pozostaje tylko niewiele osób, do których informacja jeszcze nie dotarła. Docieranie do nich, z powodu słabszych kontaktów, jest powolne. W 1994 r. powstało już tylko 6 biur turystycznych. Taki przebieg procesu dobrze opisuje krzywa $s$-kształtna, to jest krzywa logistyczna (rys. 5). Odpowiada to sytuacji, w której każdy zwolennik nowości przekazuje ją w jednostce czasu pewnej stałej liczbie osób, przy czym niektóre już są zwolennikami nowości. Otrzymujemy przy tym założeniu następujące równanie różniczkowe (C o l e m a n 1968):

$$
\frac{d t}{d x}=K x(N-x)
$$

gdzie: $K$ - stała dyfuzji (współczynnik proporcjonalności), $N$ - całkowita liczba populacji, $x$ - liczba osób będących zwolennikami nowości w czasie $t$. Całkując i przyjmując warunki początkowe, gdzie $x=1, t=0$, w ostatecznej postaci dostaniemy:

$$
x=\frac{N e^{K I N}}{(N-1)+e^{K t N}}
$$


Liczba biur

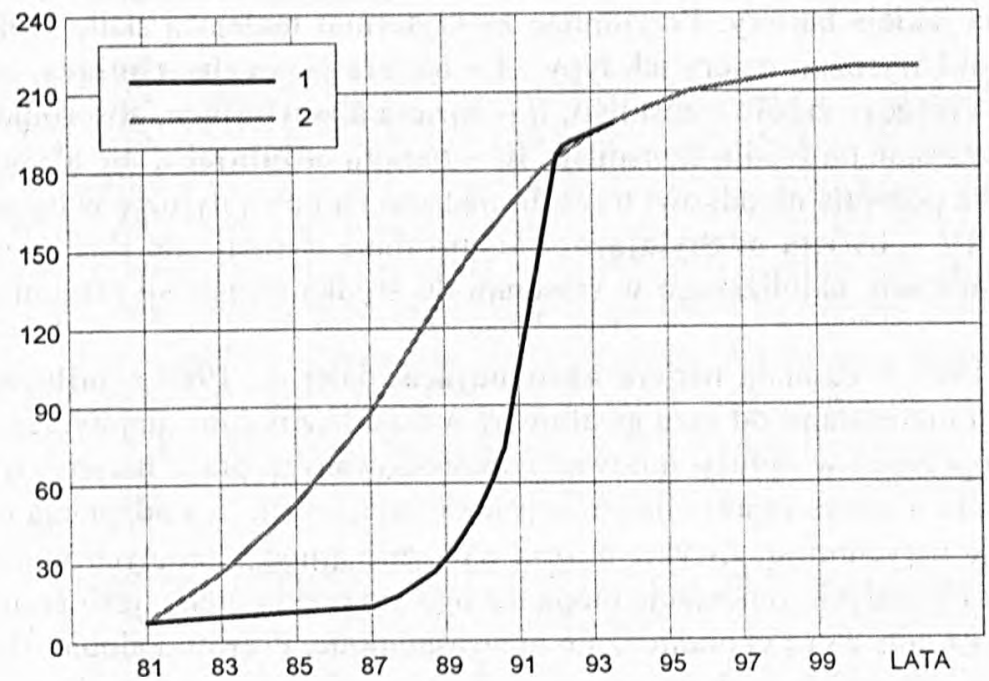

Rys. 5. Wzrost liczby biur podróży na terenie Lodzi w latach 1981-1994. 1 - krzywa rzeczywista, 2-krżywa teoretyczna

Dessin 5. L'accroissement du nombre des agences de voyages sur le terrain de Lódź dans les années 1981-1994. 1 - courbe réelle, 2-courbe théorique

W miarę rozwoju procesu dyfuzji zmienia się również jego przebieg przestrzenny. Początkowo najwięcej przekazów informacji ma miejsce w pobliżu środka przestrzeni. Biura turystyczne powstają w najbliższym otoczeniu dzielnicy centralnej w strefie drugiej. Później, w okresie szybkiej dyfuzji, wyrażonej przez środkowy odcinek krzywej, liczba przekazów w pobliżu środka maleje, wzrasta natomiast wraz z odległością. Biura podróży uruchamiane są w strefie trzeciej (rys. 2). W końcowym okresie wzrost przekazów we wszystkich częściach przestrzeni jest mniej więcej równomierny. Te trzy fazy procesu dyfuzji nazywa się odpowiednio: fazą początkowa, rozprzestrzeniania i zagęszczania. Obecnie proces ekspansji biur turystycznych na terenie Łodzi znajduje się na przełomie fazy rozprzestrzeniania i zagęszczania.

Na rysunku 5 porównano dwie krzywe, jedną obrazującą rzeczywisty rozwój biur turystycznych na terenie Łodzi i drugą ukazującą teoretyczne tempo ich powstawania, wyliczone wg przedstawionego wcześniej wzoru. Przy czym za stałą $k$ przyjęto wartość $1 / 550$, a za punkt wyjścia analizy rok 1981, kiedy to istniało 10 biur podróży. $Z$ wykresu tego widać, iż krzywa rzeczywista wykazuje znaczne odchylenie od teoretycznej. W roku 1988 powinno działać 100 biur turystycznych, jest ich tylko 15 , w 1991 - 161, a nie 63 . W latach następnych obie funkcje stopniowo zbliżają się do siebie, by w 1994 r. osiągnąc tę samą wielkość wyrażającą liczbę biur równą 198. 
Można wysunąć wniosek, że proces dyfuzji został zdeformowany na skutek działania jakiejś bariery. Przyjmując za kryterium malejącą skalę blokowania, R. S. Yuill wyróżnił cztery ich typy : I - bariera superabsorbująca, absorbuje dyfuzję i niszczy źródło transmisji; II - bariera absorbująca, absorbuje dyfuzję nie oddziałując na źródło transmisji; III - bariera odbijająca, nie absorbuje dyfuzji, lecz pozwala ośrodkowi transmitującemu na nową dyfuzję w tej samej generacji; IV - bariera odchylająca, nie absorbuje dyfuzji, ale skierowuje ją do innego miejsca, najbliższego w stosunku do środka transmisji (D o m a ń s k i 1987).

Do 1981 r. działała bariera absorbująca, dalej do 1988 r. odbijająca. Po tym roku nie nastąpił od razu gwałtowny wzrost liczby biur turystycznych, gdyż oprócz opóźnień w dyfuzji innowacji spowodowanych przez bariery, występują opóźnienia w przyswajaniu informacji już otrzymanych. Ich adaptacja nigdy nie następuje natychmiast. Zwykle można wyróżnić grupę wczesnych innowatorów i grupę opieszałych. Innowacje mogą też być nie przyswajane, jeśli podejmujący decyzje uznają że są ekonomicznie nieuzasadnione. Prawdopodobieństwo przyswojenia jest dodatnio skorelowane $\mathrm{z}$ efektywnością innowacji. Zmniejsza się, gdy wymaga ona wielkich inwestycji (D o m a ń s k i 1987).

W 1982 r. zapoczątkowano reformowanie gospodarki, co wpłynęło na mechanizm kreowania nowych przedsiębiorstw turystycznych. Część z nich powstała na skutek podziału na mniejsze jednostki firm już istniejących. W tym czasie rozpoczął się też proces tworzenia prywatnych biur turystycznych (Intertour sp. z o.o. - data powstania 1982). Funkcjonowały one początkowo jednak na podstawie starych nieaktualnych przepisów prawnych: np. o ustawy z 18 lipca 1974 r. o wykonywaniu handlu oraz niektórych rodzajów działalności przez jednostki gospodarki nieuspołecznionej. Mogły one prowadzić organizację tylko turystyki krajowej. Natomiast w zakresie zagranicznej turystyki wyjazdowej występowały w roli akwizytorów na imprezy uspołecznionych biur posiadających odpowiednie uprawnienia. Na skutek tych trudności liczba biur podróży rosła więc wolno. Sytuacja ta radykalnej zmianie uległa dopiero po wejściu w życie ustawy z 28 grudnia 1988 r., nr 41, poz. 324, której art. 1 mówi, że podejmowanie działalności gospodarczej jest wolne i dozwolone każdemu na równych prawach. Spowodowało to początkowo przyspieszanie tworzenia się nowych biur, a od $1991 \mathrm{r}$. lawinowy ich wzrost.

Model dyfuzji innowacji może też być wykorzystany do programowania rozwoju badanych zjawisk. Z przedstawionego tutaj wykresu (rys. 5) wynika, iż nasycenie przestrzeni Łodzi biurami podróży nastapi po roku 2000 na poziomie ok. 220 przedsiębiorstw, jeśli nie zmienią się obecnie istniejące warunki ich działalności bądź nie pojawią się nowe bariery. 
Pragnieniem właścicieli biur turystycznych, zwłaszcza $w$ gospodarce rynkowej, jest taka ich lokalizacja, która zapewniałaby maksymalizację obrotów i zysków. Realne staje się to przy posiadaniu możliwie największej liczby klientów, a więc i możliwie największego obszaru obsługi. Stąd też $\mathrm{m}$. in. tendencja do lokalizacji większości biur podróży w dzielnicach centralnych. Biur turystycznych nie należy jednak postrzegać jako organizacji bez reszty zainteresowanych mnożeniem zysków. Powyższy cel strategiczny należy rozpatrywać w kontekście długotrwałego utrzymania się na rynku i umacniania na nim własnej pozycji, aby w konsekwencji uzyskać korzystny wynik finansowy i osiagnaç długotrwały sukces. Cele lokalizacji są tylko jedną grupą ze wszystkich celów przedsiębiorstwa turystycznego.

Na szczegółową lokalizację biur turystycznych na terenie miasta i zmiany zachodzące w tym zakresie oddziałuje splot uwarunkowań zgodnych z ogólnymi zasadami lokalizacji handlu. Jest to dziedzina produkcji, której funkcją jest udostępnianie towarów konsumentom (Mc C a r t y, L i n d b e r g 1969). W tym przypadku towarem jest oferta turystyczna - usługa. Można wśród uwarunkowań tych wyróżnić: 1) dostępność dla konsumentów, 2) rodzaj świadczonych usług, 3) korzyści wynikające z aglomeracji (centralizacji) sprzedaży, 4) polityka władz lokalnych między innymi w zakresie czynszów, 5) elementy estetyczne, 6) kwalifikacje kadry zarządzającej.

Pod wpływem zmian tych uwarunkowań, w zależności od ich skali i kierunków, następują zmiany w lokalizacji. Są to bariery, które zakłócaja, opóźniają i modyfikują modelową dyfuzję innowacji. Podstawową tego przyczyną jest fakt, że lokalizacja wywiera wpływ na efektywność ekonomiczną działalności przedsiębiorstwa. To, czy zapewnia ona większą czy mniejszą efektywność i to tylko w krótkim czy też w dhugim okresie, zależy od trafności jej wyboru.

1. Dostępność. Związek między rozmieszczeniem usług a rozmieszczeniem popytu na nie jest szczególnie silny. Konsumenci dążą do minimalizacji wydatków czasu i pieniędzy na transport. Z ich punktu widzenia najbardziej korzystna jest więc sytuacja, w której możliwie największa liczba usług świadczona jest w pobliżu miejsca zamieszkania. Dotyczy to jednak dóbr i usług o niskich kosztach jednostkowych, bądź nabywanych względnie często. Usługa turystyczna posiada dość wysoki koszt jednostkowy i nabywana jest względnie rzadko częstotliwość zakupów na jednego klienta jest mała. Lokalizacja biur podróży w bliskiej odległości od konsumentów z powodów ekonomicznych jest więc w większości niemożliwa. Dlatego też narasta tendencja do uruchamiania ich w miejscach o charakterze centralnym w stosunku do większej liczby konsumentów, a więc najlepiej w „city”. Zapewnia to łatwą dostępność dla klientów, gdyż centrum miasta jest obszarem dobrze skomunikowanym z każdą z jego 
części. Wyniki badań potwierdziły to, iż prawidłowość ta charakterystyczna jest też $\mathrm{m}$. in. i dla Łodzi.

W celu oszacowania zależności liczby biur podróży od oddalenia od centrum miasta wyznaczono krzywą regresji (rys. 6). Zestawiono odległość centroidu biur turystycznych danej jednostki urbanistycznej od centroidu dla Łodzi, $\mathrm{z}$ liczbą biur $\mathrm{w}$ danej jednostce. Funkcja wymierna, która opisuje powyższy związek, jest postaci:

$$
y=\frac{a}{x^{2}+x}
$$

gdzie: $a$ - parametr równy w przypadku Łodzi 18,$2 ; y$ - zmienna zależna liczba biur podróży; $x$ - zmienna niezależna - odległość. Jej wykresem jest krzywa zbliżona do hiperboli. Funkcja ta mówi, że liczba biur podróży jest odwrotnie proporcjonalna do kwadratu odległości od centroidu powiększonego o tę odległość.

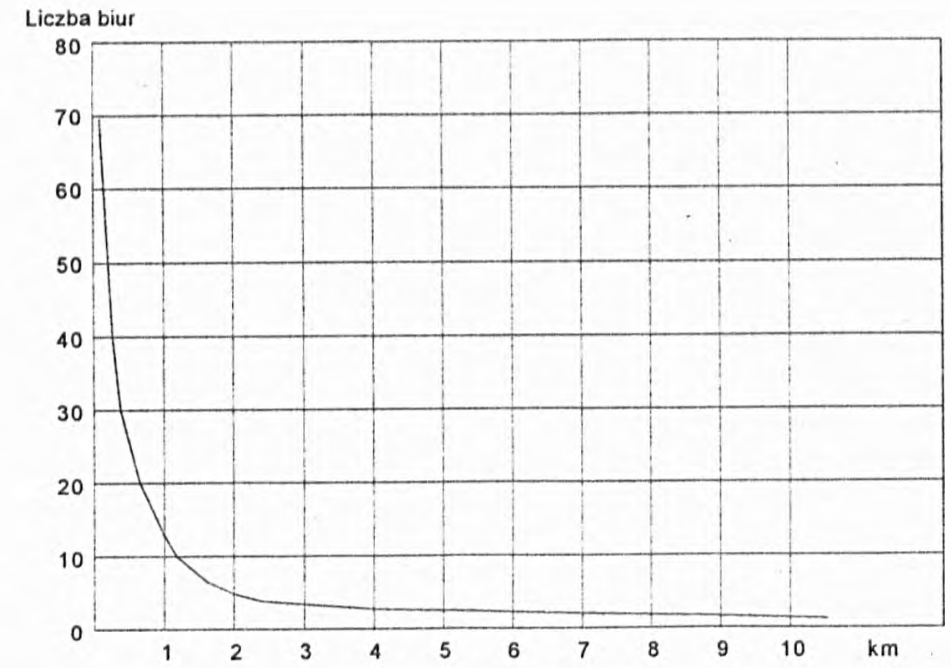

Rys. 6. Krzywa regresji liczby biur podróży w zależności od odległości od centroidu na terenie Lodzi w $1994 \mathrm{r}$.

Dessin 6. La courbe de régression du nombre de voyages selon l'éloignement du centroïde sur le terrain de Łódź en 1994

Na podstawie tego równania regresji wyliczono współczynnik korelacji:

$$
r=\sqrt{1-\phi^{2}}
$$


gdzie: $\phi^{2}$-współczynnik zbieżności:

$$
\phi^{2}=\frac{\sum\left(y_{i}-\hat{y}_{i}\right)^{2}}{\sum\left(y_{i}-\bar{y}_{i}\right)^{2}}
$$

$y_{i}$ - zaobserwowane wartości zmiennej $y ; \hat{y}_{i}$ - wartość teoretyczna zmiennej $y$ obliczona na podstawie równania regresji; $\bar{y}_{i}-$ średnia arytmetyczna wartości zmiennej $y$.

Uzyskana wartość współczynnika zbieżności $\phi^{2}=0,08$ potwierdza, że istnieje duża zbieżność danych empirycznych z teoretycznymi, a zatem przyjęta postać funkcji regresji dobrze opisuje zachodząca zależność między odległością a liczbą biur podróży. Jednocześnie współczynnik korelacji $r=0,96$ wskazuje na bardzo silną korelację między tymi zmiennymi. Kwadrat współczynnika korelacji, zwany współczynnikiem determinacji, pomnożony przez 100 (w tym przypadku $r^{2}=0,922$ ) oznacza, że odległość od centroidu tłumaczy malejąca liczbę biur turystycznych w $92,2 \%$, zaś $7,8 \%$ przypada na zmienność nieznana, przypadkowa.

Część biur lokuje się jednak nie w dzielnicach centralnych miasta, a w bezpośrednim sąsiedztwie najliczniej reprezentowanej grupy klientów w nowych osiedlach mieszkaniowych, zamieszkałych przez robotników i klasę średnią. Wynika to z kilku powodów. W biurach turystycznych usługi mogą być świadczone przez niewielkie zespoły ludzi, a czasem i przez poszczególne osoby. Małe prywatne biura aby osiągnaćc zamierzoną efektywność ekonomiczną bazują na rynku lokalnym zawężając swój obszar obsługi. Wszystkie łódzkie biura położone $w$ trzeciej strefie zatrudniają na stałe maksimum 3 osoby. Dodatkowym bodźcem ekonomicznym są czynsze nieraz dziesięciokrotnie niższe niż na obszarze śródmiejskim. Następnym powodem do lokalizacji poza centrum może być rodzaj świadczonych usług.

2. Rodzaj świadczonych uslug. Biura położone peryferyjnie proponuja klientom często specjalne korzyści, jak np. niżzze ceny czy specyficzną ofertę wyjazdów (np. wycieczki handlowe), bądź też muszą posługiwać się szczególnie efektywną reklamą. Ma to skłonić konsumentów do substytucji korzyści, np. niskich cen, w miejsce niekorzyści, np. utrudnionej dostępności - dłuższego i droższego dojazdu. Stosowane w praktyce kryterium rodzaju świadczonych usług prowadzi do określonej specjalizacji biura turystycznego, tzn. do wyboru określonych segmentów rynku. Można jednocześnie przyjąć za regułę ogólną, że tendencja do lokalizacji w pobliżu konsumentów zmienia się odwrotnie proporcjonalnie do stopnia specjalizacji usług. Na przykład biura zajmujące się głównie sprzedażą biletów autobusowych w komunikacji międzynarodowej znajdują się w dzielnicy centralnej (Cacadu, Europol, Duotourist itd.).

Generalnie jednak wszystkie łódzkie biura podróży starają się organizować różne formy wyjazdów turystycznych. Są to zarówno krajowe, jak i zagraniczne 
wycieczki, campingi, wczasy, kolonie, obozy młodzieżowe stacjonarne i wędrowne, zimowiska, wyjazdy pielgrzymkowe. Pośredniczą one również w sprzedaży usług transportowych i różnych imprez rozrywkowych.

W 1993 r. biura w większym stopniu nastawione były na obsługę tanich wyjazdów zagranicznych, aniżeli krajowych. Z ogólnej liczby 221,1 tys. obsłużonych klientów 101,3 tys. (45,6\%) uczestniczyło w wyjazdach krajowych (tab. III). Wyjazdy poza Europę i basen Morza Śródziemnego w swej ofercie proponowalo tylko $11(5,6 \%)$ największych biur usytuowanych centralnie (Orbis, Air Tours itd.). Dwa biura (1\%) oferowały wyjazdy tylko za granicę, $17(8,6 \%)$ tylko krajowe.

T a b e I a III

Rozmieszczenie biur podróży w zależności od liczby obslużonych turystów w 1993 r.

La localisation des agences de voyages selon le nombre des clients en 1993

\begin{tabular}{|c|c|c|c|c|c|c|c|c|}
\hline \multirow{3}{*}{$\begin{array}{c}\text { Biura wg wielkości } \\
\text { - liczby obshuźonych turystów }\end{array}$} & \multicolumn{8}{|c|}{ Biura w poszczególnych strefach } \\
\hline & \multicolumn{2}{|c|}{$\begin{array}{c}\mathrm{l} \\
0,0-1,5 \mathrm{~km}\end{array}$} & \multicolumn{2}{|c|}{$\begin{array}{c}\text { II } \\
1,5-3,0 \mathrm{~km} \\
\end{array}$} & \multicolumn{2}{|c|}{$\begin{array}{c}\text { III } \\
3,0-6,0 \mathrm{~km} \\
\end{array}$} & \multicolumn{2}{|c|}{ razem } \\
\hline & liczba & $\%$ & liczba & $\%$ & liczba & $\%$ & liczba & $\%$ \\
\hline 1. Male (do 1100 ) & 62 & 51,2 & 21 & 63,6 & 28 & 73,7 & 111 & 57,8 \\
\hline 2. Średnie $(1100-2200)$ & 44 & 36,4 & 12 & 36,4 & 10 & 26,3 & 66 & 34,4 \\
\hline 3. Duże (powyżej 2200) & 15 & 12,4 & - & - & - & - & 15 & 7,8 \\
\hline Ogólem & 121 & 100,0 & 33 & 100,0 & 38 & 100,0 & 192 & 100,0 \\
\hline
\end{tabular}

Szeroki profil usługowy daje firmie turystycznej większe możliwości przetrwania niepomyślnej sytuacji na rynku (np. załamania się popytu na usługi pewnego segmentu tego rynku). Duże firmy turystyczne moga koncentrować swoją działalność na jakimś większym segmencie rynku lub kilku mniejszych. Natomiast firmy mniejsze mogą osiagać korzystne efekty ekonomiczne koncentrując się na obsłudze tylko jednego, niezbyt dużego segmentu.

Część biur odwołuje się do specyficznego nabywcy usługi. Na przykład OST Gromada obsługuje środowisko ludności wiejskiej, miłośników sportu PPISiT Sports-Tourist, turystów zmotoryzowanych - BTZ PZMot., młodzież BPT Almatur, BT Almatramp i BZTM Juventur, turystę o wysokich dochodach preferującego podróże lotnicze - BTPLL LOT Air Tours. Wszystkie one położone są również centralnie.

3. Aglomeracja. To, czy jednostki dążą do lokalizacji w pobliżu innych zależy głównie od tego, czy klienci pragną mieć możność odwiedzenia przed dokonaniem zakupu kilku przedsiębiorstw tej samej branży dla celów porównawczych. Ponieważ konsument chce mieć pewność, że wybrał najlepiej konfrontuje ze sobą oferty biur konkurencyjnych; dlatego lokują się one niedaleko od 
siebie. W tym też właśnie tkwi teoretyczne uzasadnienie tworzenia się ulic handlowych (np. ul. Piotrkowska) lub lokalnych ośrodków handlowych w granicach miasta. Tam też chętnie zakładane są biura turystyczne. O znacznym stopniu ich centralizacji świadczą między innymi wyliczone wcześniej współczynniki koncentracji, przekraczające 0,9 .

4. Czynsze. Polityka gospodarcza władz lokalnych i uwarunkowania wolnego rynku maja głównie wpływ na wielkość czynszu w zajmowanych przez biura turystyczne lokalach, ustalając z reguły wysokie stawki w obszarach centralnych miasta, a niższe w miarę zbliżania się ku jego peryferiom. Uchwała Rady Miejskiej z 5 września 1990 r. określiła, iż podstawową formą wynajmu lokali użytkowych $w$ budynkach stanowiących mienie komunalne jest przetarg. Ponadto podzieliła ona miasto na pięć stref $\mathrm{i}$ ustaliła odrębne przepisy prawne dotyczące form własności i wielkości czynszów za lokale użytkowe dla każdej strefy (od 16 grudnia 1992 r. wprowadzono podział na 13 stref). Lokalizacja $w$ centrum pociagga więc za sobą znaczne wydatki związane $\mathrm{z}$ utrzymaniem lokalu. Użytkowanie jednego metra kwadratowego kosztowało tam nawet w $1994 \mathrm{r}$. do 500 tys. zł. Sprzyja to oszczędnemu korzystaniu z wynajmowanych lokali. Tylko $4(2 \%)$ biura wynajmowały pomieszczenia o powierzchni powyżej $100 \mathrm{~m}^{2}$, $9(4,5 \%)$ od 40 do $100 \mathrm{~m}^{2}$, reszta $-92,5 \%$ od 12 do $40 \mathrm{~m}^{2}$. Wszystkie biura o powierzchni powyżej $40 \mathrm{~m}^{2}$ znajdowaly się jednak w centrum miasta. Wynika stąd fakt, że mimo wszystko przeważały korzyści wynikające z centralnego położenia niż ewentualnie niższych czynszów, choć niektóre biura rezygnowały z części zajmowanych powierzchni, inne zaś lokowały się w głębi podwórek, w oficynach. Na przykład na 44 biura polożone przy ul. Piotrkowskiej tylko 5 $(11,4 \%)$ znajdowało się bezpośrednio przy ulicy. Jest to $\mathrm{m}$. in. konsekwencja wspomnianych powyżej postanowień. Zgodnie z nimi lokale mające wejście lub witrynę bezpośrednio z ulicy Piotrkowskiej na odcinku od pl. Wolności do ul. Żwirki i Wigury, mieszczące się na parterze lub pierwszym piętrze, zaliczono do strefy I, a lokale w podwórzach posesji do II, gdzie stawki czynszów były znacznie niższe (Wytyczne..., 1990).

Małe biura usytuowane poza śródmieściem, poszukując dodatkowych korzyści ekonomicznych zajmują stosunkowo niewielkie lokale, gdyż obsługują mniejszą liczbę klientów.

5. Elementy estetyczne. Lokalizacja w dzielnicach charakteryzujących się zniszczoną, nieestetyczną zabudową nie może być preferowana przez właścicieli biur turystycznych. Te części miasta są z reguly niebezpieczne i zamieszkane przez ludność najbiedniejszą. Sieć innych usług jest niewielka. Stanowi to barierę odpychającą klientów. W drugiej strefie - przejściowej - na terenie Łodzi mieści się najmniejszy odsetek $(16,9 \%)$ biur podróży i zlokalizowane są one przy głównych ciągach komunikacyjnych. Atrakcją są tutaj stosunkowa bliskość centrum i mniejsze czynsze. 
6. Kwalifikacje kadry zarządzającej. Poziom wykształcenia, wcześniejsze doświadczenia decydentów wpływają na trafność wyboru lokalizacji - na jej efektywność ekonomiczną. To właściciel analizując jej elementy decyduje się na określone ulokowanie biura w przestrzeni miejskiej.

Reasumując należy stwierdzić, że lokalizacja biura turystycznego w pobliżu klienta jest na tyle możliwa, na ile pozwala na to własna specyfika tego biura. Każde z rozwiązań, czy to lokalizacja w strefie pierwszej, drugiej bądź trzeciej ma swoje plusy i minusy, żadne $z$ nich nie jest optymalne, może być co najwyżej mniej lub bardziej efektywne ekonomicznie. Dwie siły, dążenie właściciela do maksymalizacji zysku i klienta do minimalizacji wydatków działaja w przeciwnych kierunkach, tak że układ rozmieszczenia biur podróży jest wynikiem kompromisu między nimi. Biura o zasięgu przestrzennym ogólnokrajowym, ponadregionalnym, czy regionalnym lokują się w centrum miasta, a typowo lokalne poza nim.

Z wyżej wymienionych czynników największe znaczenie w ukształtowaniu się takiej lokalizacji miała dostępność dla konsumentów rozumiana jako odległość od centrum miasta i związane z tym korzyści aglomeracji na terenie CBD, o czym świadczą wyliczone współczynniki koncentracji i korelacji. Inne cechy w przypadku Łodzi miały niewielki wplyw na lokalizację biur podróży.

\section{TYPOLOGIA ŁÓDZKICH BIUR PODRÓŻY}

Typologię biur turystycznych przeprowadzono z punktu widzenia ich lokalizacji i jej czynników, które zadecydowały o ich położeniu. Dodatkowo wzięto pod uwagę związane z tym: 1) bezpośredni lub pośredni stosunek do klienta, 2) rok powstania, 3) wielkość biura. W celu sprawdzenia istotności tych czynników zastosowano test $\chi^{2}$,

$$
\chi^{2}=\sum_{i=1}^{k} \sum_{j=1}^{l} \frac{\left(O_{i j}-E_{i j}\right)^{2}}{E_{i j}}
$$

a roli, jaką pełnią w lokalizacji, współczynnik korelacji Cramera

$$
V=\sqrt{\frac{\chi^{2}}{N \min (k-1, l-1)}}
$$

gdzie: $k$ - liczba kategorii; $l$ - liczba prób; $N$ - całkowita liczba obserwacji; $O_{i j}$ - obserwowana częstość w kategorii $i$ próby $j ; E_{i j}$ - oczekiwana częstość w kategorii $i$ próby $j$. Współczynnik $V$ Cramera stosowany przy badaniach współza- 
leżności zjawisk $\mathrm{z}$ tablic kontyngencji większych niż $2 \times 2$ zmienia się $\mathrm{w}$ granicach od 0 do 1 . Wyniki zestawiono w tabelach. Dla $n=4 \mathrm{i} n=6, \chi_{0,05}^{2}$ wynosi odpowiednio 9,49 i 12,59; gdzie $n=(k-1)(l-1)$ i oznacza liczbę stopni swobody.

1. Biorąc pod uwagę bezpośredni lub pośredni stosunek biur turystycznych do klienta dzieli się je na następujące grupy: detalistów, hurtowników, producentów-touroperatorów ( $\mathrm{L}$ a z a r e k 1980). Obecnie zacierają się jednak różnice między nimi. Powstają biura o profilu mieszanym. Mogą one mieć następującą strukturę: a) producent-hurtownik-detalista (Orbis, Turysta, Gromada, Sports-Tourist), b) hurtownik-detalista (Cacadu, Holiday Tours), c) producentdetalista (Tourpol, Almatramp, Panorama).

Większość biur na terenie Łodzi, to jest 107 (54\%), posiada właśnie profil mieszany o różnej strukturze (tab. I). Reszta to detaliści. Ponieważ do przedsiębiorstw o profilu mieszanym należy większość dużych reprezentacyjnych biur, skupiają się one w centrum (wszystkie o strukturze producent-hurtownik-detalista i hurtownik-detalista). Stanowią one $74 \%$ (91) biur położonych w strefie pierwszej i 86\% (86) na terenie wcześniej wyróżnionego centrum handlowo-instytucjonalno-administracyjnego. Obsługują też one większość klientów, bo w 1993 r. 76,1\%, to jest 168,2 tys. osób, wykorzystując wszystkie atuty lokalizacji centralnej. Zatrudniają też większość pracowników - 54,6\%. Między odległością od centrum (położeniem w określonej strefie) a kryterium bezpośredniości w stosunku do klienta zależność jest istotna $\left(\chi^{2}=54,3\right)$, średnia $V=0,37$.

2. Biorąc pod uwagę datę powstania biura należy stwierdzić, że te, które utworzono wcześniej, skupiają się w centrum. W ostatnich latach duża liczba biur turystycznych zaczęła działalność w dzielnicy centralnej. Na skutek tego współczynnik korelacji Cramera, obrazujący zależność między rokiem ich powstania (tzn. do: 1981, 1988, 1991, 1994 włącznie) a odległością od centrum (rozmieszczeniem w poszczególnych strefach), choć jest istotny $\left(\chi^{2}=21,5\right)$, wynosi tylko 0,23 , co wskazuje na słabą siłę związku (tab. II).

3. Wielkość biura turystycznego można wyrazić $m$. in. poziomem zatrudnienia i liczbą osób obsłużonych. Średnio jedno biuro zatrudniało w 1994 r. 3 osoby i obsłużyło w 1993 r. 1116 klientów. Na tej podstawie wyróżniono trzy grupy biur: małe, do 3 osób zatrudnionych i obsługujące do 1,1 tys. turystów, średnie 4-6 osób zatrudnionych i obsługujące 1,1-2,2 tys. klientów oraz duże, zatrudniające powyżej 6 pracowników i obsługujące powyżej 2,2 tys. konsumentów (tab. III i IV).

Widać z tego, że lokalizacja biur podróży w niewielkim stopniu jest zależna od ich wielkości, choć wszystkie przedsiębiorstwa duże oraz znaczna część biur średnich, tj. 79,6\% biorąc pod uwagę zatrudnienie i $66,7 \%$ liczbę obsłużonych turystów, położone są w strefie centralnej. W strefie trzeciej znajdują się tylko przedsiębiorstwa małe, gdy rozpatrujemy liczbę pracowników, bądź stanowią one $75,6 \%$ wszystkich biur, gdy bierzemy pod uwagę wielkość obsługi. Centra- 
Tabela IV

Rozmieszczenie biur podróży w zależności od wielkości zatrudnienia w $1994 \mathrm{r}$.

La localisation des agences de voyages selon le nombre des employés en 1994

\begin{tabular}{|c|c|c|c|c|c|c|c|c|}
\hline \multirow{3}{*}{$\begin{array}{c}\text { Biura wg wielkości } \\
\text { zatrudnienia }\end{array}$} & \multicolumn{8}{|c|}{ Biura w poszczególnych strefach } \\
\hline & \multicolumn{2}{|c|}{$\begin{array}{c}\mathrm{I} \\
0,0-1,5 \mathrm{~km} \\
\end{array}$} & \multicolumn{2}{|c|}{$\begin{array}{c}\text { II } \\
1,5-3,0 \mathrm{~km}\end{array}$} & \multicolumn{2}{|c|}{$\begin{array}{c}\text { III } \\
3,0-6,0 \mathrm{~km} \\
\end{array}$} & \multicolumn{2}{|c|}{ razem } \\
\hline & liczba & $\%$ & liczba & $\%$ & liczba & $\%$ & liczba & $\%$ \\
\hline 1. Male (do 3 osób) & 67 & 54,5 & 23 & 67,6 & 41 & 100,0 & 131 & 66,2 \\
\hline 2. Średnie (4 do 6 osób) & 43 & 35,0 & 11 & 32,4 & - & - & 54 & 27,3 \\
\hline 3. Duze (7 i więcej) & 13 & 10,5 & - & - & - & - & 13 & 6,5 \\
\hline Ogólem & 123 & 100,0 & 34 & 100,0 & 41 & 100,0 & 198 & 100,0 \\
\hline
\end{tabular}

lizacja usług wpływa więc na wzrost optymalnej wielkości zakładu. Biura większe są też lepiej wyposażone (np. skomputeryzowane, bądź posiadają wlasne środki transportu).

Współczynnik V Cramera, określający rozmieszczenie biur podróży w zależności od ich wielkości wyrażonej liczbą obsłużonych turystów, wynosi 0,18 , $\left(\chi^{2}=12,45\right)$, a zatrudnieniem - $0,31\left(\chi^{2}=38,98\right)$. Ponieważ wartość $\chi^{2}$ przekracza wartość krytyczną, świadczy to o słabym, ale istotnym związku między tymi cechami.

Wielkość biur można wyrazić również analizując zajmowane przez nie powierzchnie użytkowe. Rozmieszczenie biur turystycznych w poszczególnych strefach w zależności od tego parametru przedstawia tab. V. Współczynnik $V$ Cramera równa się $0,15, \chi^{2}-9,3$ co wskazuje, że korelacja między tymi cechami jest bardzo mała i nieistotna.

Rozmieszczenie biur podróży w Łodzi w zależności od wielkości powierzchni uzytkowej w $1994 \mathrm{r}$.

La localisation des agences de voyages selon la superficie des locaux occupés par ces agences en 1994

\begin{tabular}{|c|c|c|c|c|c|c|c|c|}
\hline \multirow{3}{*}{$\begin{array}{c}\text { Biura wg } \\
\text { powierzchni użytkowej }\end{array}$} & \multicolumn{8}{|c|}{ Biura w poszczególnych strefach } \\
\hline & \multicolumn{2}{|c|}{$\begin{array}{c}\mathrm{l} \\
0,0-1,5 \mathrm{~km}\end{array}$} & \multicolumn{2}{|c|}{$\begin{array}{c}\mathrm{II} \\
1,5-3,0 \mathrm{~km}\end{array}$} & \multicolumn{2}{|c|}{$\begin{array}{c}11 \mathrm{I} \\
3,0-6,0 \mathrm{~km} \\
\end{array}$} & \multicolumn{2}{|c|}{ razem } \\
\hline & liczba & $\%$ & liczba & $\%$ & liczba & $\%$ & liczba & $\%$ \\
\hline Powyżej $100 \mathrm{~m}^{2}$ & 4 & 3,3 & - & - & - & - & 4 & 2,0 \\
\hline $40-100 \mathrm{~m}^{2}$ & 5 & 4,1 & 4 & 11,8 & - & - & 9 & 4,5 \\
\hline do $40 \mathrm{~m}^{2}$ & 114 & 92,6 & 30 & 88,2 & 41 & 100,0 & 185 & 93,5 \\
\hline Ogólem & 123 & 100,0 & 34 & 100,0 & 41 & 100,0 & 198 & 100,0 \\
\hline
\end{tabular}


Na tej podstawie wyróżniono następujące typy biur podróży (rys. 7):
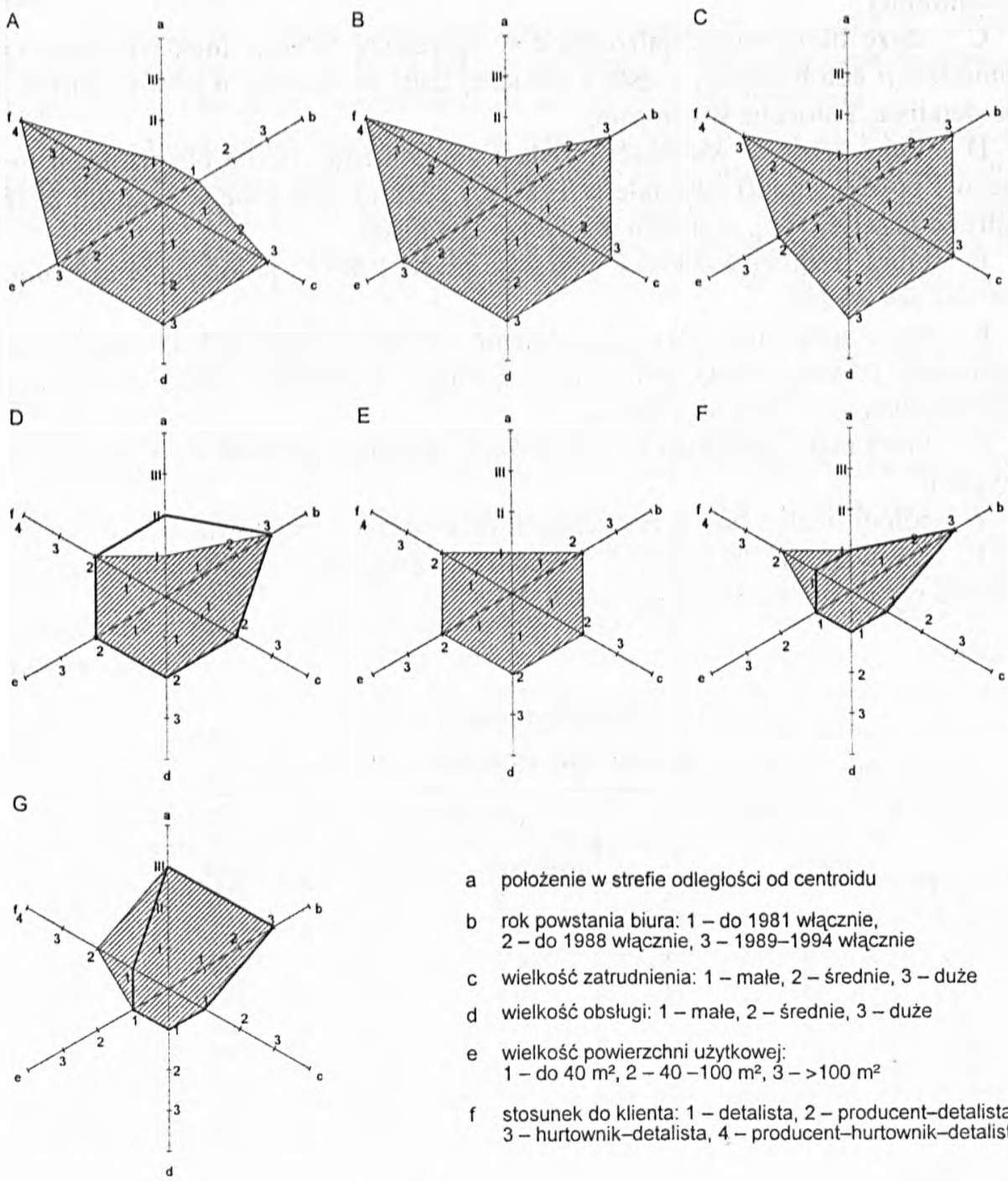
a położenie w strefie odległości od centroidu
b rok powstania biura: 1 - do 1981 wlacznie, 2- do 1988 wlącznie, 3 - 1989-1994 wlącznie
c wielkość zatrudnienia: 1 - małe, 2 -średnie, 3 -duże
d wielkość obsługi: 1 - male, 2 - średnie, 3 -duże
e wielkość powierzchni użytkowej: 1-do $40 \mathrm{~m}^{2}, 2-40-100 \mathrm{~m}^{2}, 3->100 \mathrm{~m}^{2}$
stosunek do klienta: 1 - detalista, 2-producent-detalista,
3- hurtownik-detalista, 4 - producent-hurtownik-detalista,

Rys. 7. Typy łódzkich biur podróży

Dessin 7. Les types des agences de voyage de Lódź

A - duże (znaczna powierzchnia, zatrudnienie i liczba obsłużonych klientów), mające szeroką ofertę, położone w centrum, powstałe do $1981 \mathrm{r}$. włącznie, przekształcone $\mathrm{z}$ dawnych jednostek państwowych bądź spółdzielczych w spół$\mathrm{ki}$, o profilu producent-hurtownik-detalista; 
B - duże prywatne biura bądź spółki powstałe w 1989 r. i później, o szerokim wachlarzu usług i profilu producent-hurtownik-detalista, położone w strefie centralnej;

C - duże biura wyspecjalizowane w sprzedaży biletów międzynarodowej komunikacji autobusowej, często i lotniczej bądź promowej, o profilu hurtownik-detalista, położone w centrum;

D - biura średniej wielkości (średnie zatrudnienie, liczba obsłużonych turystów i powierzchnia) powstałe w 1989 r. i później, położone w centrum bądź w strefie przejściowej, o profilu producent-detalista;

E - biura średniej wielkości, powstałe przed 1989 r., położone w centrum, o profilu jak wyżej;

F - biura małe (niewielkie zatrudnienie i liczba obsłużonych klientów oraz zajmowana powierzchnia), położone w centrum, o profilu producent-detalista bądź detalista, powstałe po 1989 r.;

G - biura małe, położone na peryferiach, powstałe po 1989 r., o profilu jak w typie F.

W ogólnej liczbie biur turystycznych przeważają zdecydowanie te o typach E i F, stanowiąc $66,2 \%$ (131). Szczegółowe zestawienie liczby biur w zależności od typu przedstawione jest w tab. VI .

Tabela VI

Typy łódzkich biur podróży w $1994 \mathrm{r}$.

Les types des agences de voyage en 1994

\begin{tabular}{|c|c|c|c|c|c|r|}
\hline \multirow{2}{*}{ Typ } & \multicolumn{2}{|c|}{ Biura podróży } & \multicolumn{2}{c|}{${\text { Obsłużeni }{ }^{\mathrm{a}}}^{2}$} & \multicolumn{2}{c|}{ Zatrudnienie $^{-}$} \\
\cline { 2 - 7 } & liczba & $\%$ & liczba (tys.) & $\%$ & liczba & \multicolumn{1}{c|}{$\%$} \\
\hline A & 7 & 3,5 & 24,8 & 11,2 & 79 & 11,7 \\
B & 3 & 1,5 & 16,1 & 7,3 & 49 & 7,3 \\
C & 3 & 1,5 & 14,2 & 6,4 & 28 & 4,1 \\
D & 48 & 24,2 & 76,8 & 34,7 & 239 & 35,5 \\
E & 6 & 3,1 & 10,1 & 4,6 & 34 & 5,0 \\
F & 67 & 33,8 & 42,5 & 19,2 & 131 & 19,4 \\
G & 64 & 32,4 & 36,6 & 16,6 & 115 & 17,0 \\
\hline Ogólem & 198 & 100,0 & 221,1 & 100,0 & 675 & 100,0 \\
\hline
\end{tabular}

a $1993 \mathrm{r}$.

\section{WNIOSKI}

1. Większość biur podróży skupia się w centrum Lodzi, gdzie wykazuje tendencję do znacznej koncentracji. Świadczą o tym wyliczone współczynniki koncentracji $K$ przekraczające 0,9 i umiejscowienie środka ciężkości oraz mediany 
przestrzennej. Dzięki temu biura turystyczne mogą być jednym z wyznaczników dzielnicy typu , city”.

2. Wraz ze wzrostem liczby biur podróży maleje ich koncentracja, a zwiększa się dyspersja. Nowe biura lokują się raczej w południowych dzielnicach Łodzi, o czym świadczy przesuwanie się w tym kierunku centroidu.

3. Rozmieszczenie biur podróży na terenie Łodzi zmienia się wg określonej prawidłowości. Stwierdzono, że biura lokowane są najpierw w dzielnicy centralnej (strefa I), później w jej najbliższym sąsiedztwie w strefie przejściowej (strefa II), a następnie dalej tj. w nowych osiedlach mieszkaniowych (strefa III). W strefie IV biura turystyczne jeszcze nie występuja. W city koncentruje się najwięcej i największych biur podróży.

4. Zjawisko rozprzestrzeniania się biur turystycznych $w$ przestrzeni miasta można opisać przy pomocy modelu dyfuzji innowacji. Proces ten ma charakter ekspansywny. Znajduje się on na przełomie fazy rozprzestrzeniania i zagęszczania.

5. Układ rozmieszczenia biur turystycznych jest wynikiem kompromisu między dążeniem przedsiębiorstwa do maksymalizacji zysku i klienta do minimalizacji wydatków czasu i pieniędzy. Tak więc najważniejszymi czynnikami lokalizacji są dostępność dla klienta w powiązaniu z korzyściami aglomeracji promujące lokalizację w centrum. Świadczy o tym współczynnik korelacji $r=0,96$ i determinacji $r^{2}=0,922$ oraz krzywa regresji liczby biur podróży w zależności od ich odległości od centroidu. Na układ ten wpływają także: rodzaj świadczonych usług dający możliwości lokalizacyjne zależne od specjalizacji oraz wielkość czynszu dopingująca do usytuowania przedsiębiorstwa na peryferiach. Pewną rolę odgrywają tu też elementy estetyczne, preferujące lokalizację $w$ dzielnicach bardziej reprezentacyjnych i kwalifikacje kadry zarządzającej.

6. Powyższe czynniki powodują, że biura duże o szerokiej gamie usług bądź specyficznej specjalizacji lokuja się w centrum (typy: A, B, C), natomiast małe, o przeciętnej gamie usług, czasem oferujące specjalne korzyści, nie tylko w city, ale i na peryferiach (typy: $F, G$ ).

\section{PIŚMIENNICTWO}

C o I e m a n J., 1968, Wstęp do socjologii matematycznej, PWN, Warszawa.

D o m a ń s k i R. 1987, Teoretyczne podstawy geografii ekonomicznej, PWE, Warszawa.

$\mathrm{\iota}$ a z a r e k R., 1980, Biuro podróży. Pojęcia podstawowe, „Ruch Turystyczny” z. 2/52.

M a $\mathrm{c}$ z a k A., 1994, Wyjazdy turystyczne organizowane przez tódzkie biura podróży w 1990 roku, maszynopis w Katedrze Geografii Miast i Turyzmu Uniwersytetu Łódzkiego.

M c C a r t y H. H., L i n d b e r g J. B., 1969, Wprowadzenie do geografii ekonomicznej, PWN, Warszawa.

N o r c 1 i f f e G. B., 1986, Statystyka dla geografów, PWN, Warszawa.

P a c h o l c z y k A., 1993, Przemiany wtasności i funkcji ustugowej ulicy Piotrkowskiej, maszynopis pracy magisterskiej w Katedrze Geografii Politycznej i Studiów Regionalnych Uniwersytetu Łódzkiego. 
Stownik geograficzno-ekonomiczny, 1982, WSP, Kraków.

W a r s z ýn k a J., J a c k ow s k i A., 1979, Podstawy geografii turyzmu, PWM, Warszawa.

Wo 1 a n i u k A., 1994, Przemieszczanie centrum wielkiego miasta - przyklad kodzi, [w:] VII Konwersatorium Wiedzy o Mieście, Lódź.

Wytyczne podkomisji handlu $i$ uslug do realizacji uchwaly $\mathrm{nr}$ 130/90 Rady Miejskiej z dnia 05.09.1990 w sprawie zasad wynajmu lokali użytkowych $w$ budynkach stanowiqcych mienie komunalne, Lódź.

Mgr Dorian Grzelka

Studium Doktoranckie UŁ

Katedra Geografii Miast i Turyzmu

90-418 Lódź

al. Kościuszki 21
Wplynęło:

15 lutego $1996 \mathrm{r}$.

\section{RÉSUMÉ}

Le travail contient les résultats des examens dont le but était d'atteindre la connaissance de la localisation des agences de voyages sur le terrain de Łódź et d'analyser les facteurs qui en décident. Les recherches faites en 1994 ont permis de constater l'existence de 198 agences, qui en 1993 avaient 221,1 mille clients. L'examen comprenait l'état juridique et d'organisation des agences, l'an de fondation, le caractère et l'équipement du local occupé, le nombre des personnes employées et l'étendue des services touristiques.

Les examens démontrent que la plupart des agences étaient situées dans le quartier central de Lódź et considérablement concentrées. Le prouvent les coefficients de concentration $K$ dépassant 0,9 et la localisation du centre de gravité et de la médiane spatiale. Grâce à cela les agences de voyages peuvent être un déterminant du quartier du type "cité". Avec l'augmentation du nombre des agences de voyages diminue leur concentration et croît la dispersion. Les agences nouvelles se localisent plutôt dans les quartiers méridionaux de la ville, et c'est dans ce sens que se déplace le centroïde.

Le développement spatial des agences de voyages sur le terrain de Łódź s'opère selon une régularité définie. On a constaté que les agences apparaissent dans le quartier central, puis dans son voisinage le plus proche et ensuite dans les quartiers d'habitation nouveaux. Dans la cité sont concentrées les plus grandes et les plus nombreuses agences. Le phénomène de la dispersion des agences de voyages peut étre décrit à l'aide du modèle de la diffusion d'innovation. Ce processus est expansif. A Łódź, il est à la charnière de deux phases: de dispersion et de concentration.

La disposition des agences de voyages résulte du compromis entre l'entreprise, qui aspire à l'augmentation du gain et le client, qui veut minimiser les dépenses et la perte du temps. Ainsi le plus important facteur de la localisation c'est l'accessibilité au client liée aux avantages de l'agglomération que donne la localisation au centre de la ville. Le prouvent: les coefficients de corrélation $(r=0,96)$ et de détermination $(r=0,922)$, et la courbe de régression du nombre des agences de voyages suivant l'éloignement du centrö̈de. La disposition des agences de voyages est aussi influencée par le genre des services, dont dépend la localisation et par le coût du loyer, qui est plus supportable à la périphérie. Un certain rôle est joué par les facteurs estéthiques préférant la localisation dans les quartiers représentatifs et par les qualifications du cadre administratif.

Les facteurs mentionées causent que les grandes agences dont la gamme des services est large ou qui offrent des services spécifiques sont situées au centre de la ville, celles dont la gamme des services est rétrécie, mais qui offrent parfois des avantages spécifiques constituent non seulement 
à la cité, aux périphéries aussi, la majorité décidée de toutes les agences de voyages sur le terrain de Łódź $(66,2 \%)$.

En prenant en considération non seulement les facteurs de la localisation mais en surplus le rapport direct ou indirect de l'agence envers le client, ainsi que l'an de fondation et la grandeur, on a distingué sept types des agences de voyages (dessin 7), ce qui constitue l'addition de l'élaboration entière.

Traduit par Lucjan Kowalski

\section{SUMMARY}

The article presents the results of a study whose objective was to localize the travel agencies in Łódź and to establish and analyze the factors determining the localization. It was observed that in 1994 there were 198 agencies which in 1993 had served 221,1 thousand people. The survey covered their legal-organizational status, the year they were started, the character and standard of the rented facilities, the number of employees and the range of services.

The study proves that most travel agencies can be found in the central district of Łódź, where they show a tendency towards considerable concentration. This has been proved by the calculated $K$-coefficient exceeding 0,9 and by locating the centre of gravity and the spatial median. Due to that, travel agencies can be one of the denominators of a district of the „city” type. The higher the number of travel agencies, the smaller their concentration, the bigger the dispersion. New travel agencies appear rather in the south of Łódź, which is proved by the centroid moving in this direction.

The spatial development of travel agencies in Łódź occurs according to a certain regularity. It has been found that the agencies first appear in the central district, then in its closest vicinity, and then in the new housing districts. The largest number of the biggest travel agencies can be found in the city. The phenomenon of travel agencies spreading in the space of the city can be described with the model of the innovation diffusion. This is an expansive process. In Lódź it exists at the stage between the phase of spreading and the phase of congesting.

The arrangement of the travel agencies results from the compromise between the company's objective, which is maximizing profits, and the costomer's objective, which is minimizing the loss of time and money. Therefore the most important factor of localization is being accessible to the customer, along with the benefit of agglomeration promoting localization in the centre. It is proved by the correlation coefficient $r=0,96$, the determination coefficient $r=0,922$ and the regression curve of the number of travel agencies depending on their distance from the centroid. The arrangement is also influenced by: 1) the kind of services on offer which create localization possibilities dependent on specialization, 2) the rent, which makes it more profitable to localise a company on the peripheries. There is also some significance in the esthetic elements which make it more preferable to localize a company in the more representative districts, as well as in the qualifications of the managers.

The above factors are the reason why big travel agencies offering a wide range of services or specifically specialized are localized in the centre, while small ones, offering a smaller range of services and sometimes extra benefits - are localized not only in the city but also on the peripheries. The latter ones constitute the majority $(66,2 \%)$ of all travel agencies in Łódź. Considering not only the localization factors but also the direct or indirect attitude of the agencies towards the customer, as well as the year an agency was started and its size, seven types of travel agencies have been isolated (Fig. 7), as a conclusion to the whole paper. 